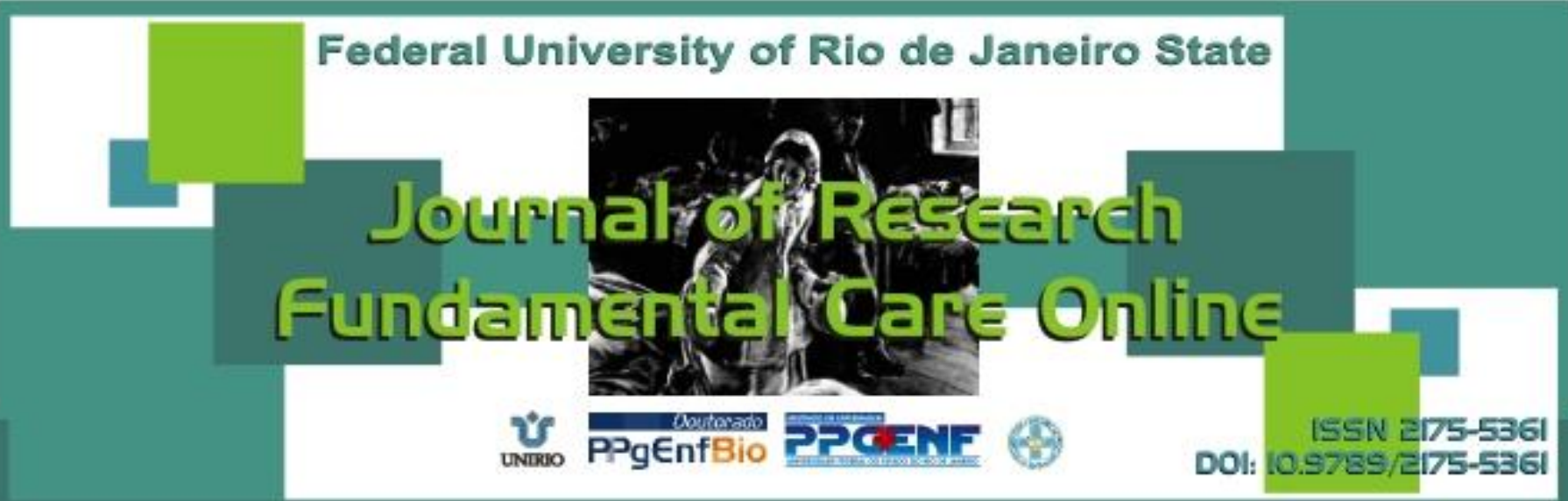

\title{
INTEGRATIVE REVIEW OF THE LITERATURE
}

\section{Adesão ao tratamento antirretroviral para o hiv e sua inter-relação com a vulnerabilidade}

\section{programática}

Adherence to antiretroviral treatment for hiv and inter-its relationship with the programmatic

vulnerability

Adhesión al tratamiento antiretroviral para el vih y su entre relación con la vulnerabilidad

programática

Samuel Spiegelberg Zuge ${ }^{1}$, Cristiane Cardoso de Paula ${ }^{2}$, Crhis Netto de Brum ${ }^{3}$, Aline Cammarano Ribeiro ${ }^{4}$, Stela Maris de Mello Padoin ${ }^{5}$

\begin{abstract}
Objective: To analyze the scientific production from the aspects of programmatic vulnerability and their relationship in adherence to antiretroviral treatment for HIV/ AIDS. Method: Narrative review of the literature. Data collection took place in February 2014 in the databases MEDLINE and LILACS and subjected to thematic content analysis. Results: A total of 16 productions, of which point out the aspects of programmatic vulnerability and their interrelation in the membership: 1) the commitment and responsibility of professionals and staff; 2) access to health services; and 3) organization of services. Conclusion: The health services intend has to promote the adherence may to establish its practices assistances with commitment and responsibility, ensuring a service organization, as well as their access. Descriptors: Nursing, Acquired immunodeficiency syndrome, HIV, Medication adherence, Health vulnerability.
\end{abstract}

\begin{abstract}
RESUMO
Objetivo: Analisar, a partir das produçoes cientmimcas, as açoes ao serviço de saúde que contribuam para a melhora da adesão ao tratamento antirretroviral para o HIV, a partir dos eixos que compõem a vulnerabilidade programática. Método: Revisão narrativa da Literatura. A coleta de dados ocorreu no mês fevereiro de 2015, nas bases de dados LILACS e MEDLINE. Foi desenvolvida a análise de conteúdo temática. Resultados: Foram analisadas 16 produções, das quais apontaram: 1) o compromisso e a responsabilidade dos profissionais e equipe; 2) o acesso ao serviço de saúde e a 3) organização do serviço. Conclusão: Os serviços de saúde no intuito de promover a saúde das pessoas e minimizar os aspectos que envolvem a vulnerabilidade programática e a adesão podem estabelecer suas práticas assistenciais com compromisso e responsabilidade, garantindo uma organização do serviço, assim como, o seu acesso. Descritores: Enfermagem, Síndrome da imunodeficiência adquirida, HIV, Adesão à medicação, Vulnerabilidade em saúde.
\end{abstract}

\begin{abstract}
Üjetivo: Anatizar, desae la proauc RESUMEN Servicios de satua que contribuyena la mejora de la adherencia al tratamento antirecroviral para el virt, desde los ejes que componen la vulnerabilidad programática. Método: Revisión narrativa de la literatura. La recolección de datos ocurrió en el mes febrero de 2015 en LILACS y MEDLINE. Fue desarrollado el análisis de contenido temático. Resultados: Un total de 16 producciones, de las cuales señalaban: 1) el compromiso y la responsabilidad de los profesionales y el personal; 2) el acceso a servicios de salud; y 3) la organización de los servicios. Conclusión: Los servicios de salud a fin de promover la salud de las personas en tratamiento antirretroviral y minimizar los aspectos relacionados con la vulnerabilidad programática y la adhesión pueden establecer sus prácticas con el compromiso y la responsabilidad, asegurando una organización de servicio así como su acceso. Descriptores: Enfermería, Síndrome de inmunodeficiencia adquirida, VIH, Cumplimiento de la medicación, Vulnerabilidad en salud.
\end{abstract}

1 Nurse. Ph.D. in Nursing by the Federal University of Santa Maria, Santa Maria, RS, Brazil. E-mail: samuelzuge@gmail.com 2 Nurco Dh $D$ in Nurcing Drofoccor of the Nurcing Courco of tho Fodoral Inivarcity of Canta Maria, Canta Maria, RC, Rrazil a Nurse. Ph.D. student in Nursing by the Federal University of Rio Grande do Sul. Professor of the Nursing Course at the Federal University of Fronteira Sul, Chapecó, SC, Brazil. 4 Nurse. Ph.D. in Nursing. Professor of the Nursing Course at the Federal University of Santa Maria, Palmeira das Missões, RS, Brazil. 5 Nurse. Ph.D. in Nursing. Professor of the Nursing Course at the Federal University of Santa Maria, Santa Maria, RS, Brazil. 


\section{INTRODUCTION}

dherence to antiretroviral treatment for Human Immunodeficiency Virus (HIV) is defined as the correlation between prescription and behavior in medication use. ${ }^{1}$ The World Health Organization (WHO) conceptualizes the adhesion as a dynamic, multifactor process, involving aspects related to psychological and social behavior, requiring shared decisions and responsibilities among the subjects, health staff and social support networks. It also needs an approach that meets sociocultural singularities, which have repercussions on the quality of life of people. ${ }^{2}$

For the antiretroviral treatment effectiveness, adhesion is considered one of the greatest determinants of response to therapy. ${ }^{3}$ Thus, to treatment adhesion be effective, it becomes necessary to consider the vulnerability of people living with HIV. Because vulnerability is shown as the result of a set of individual, collective and contextual aspects, leading to an increased susceptibility of the person to not follow the treatment. ${ }^{4}$

Early identification of vulnerability to not follow the treatment is essential in order to prevent drug resistance, which can limit access of individuals to the treatment possibilities and hence enhancing the morbidity and mortality rates. However, the issues surrounding the vulnerability assume and demonstrate, simultaneously, that is not a situation depending on the individual only, but relationships with others and their surroundings. ${ }^{4}$

Among the analytical plans of vulnerability (individual, social and programmatic), ${ }^{5}$ there is the need to expand the recognition of actions involving health services, which is implied to the concept of programmatic vulnerability, since this can interfere with adhesion to treatment.

The programmatic plan analyzes the social resources necessary for the protection of the individual, directly related to the physical, psychological and social well-being and is inter-related to other plans (individual and social). ${ }^{4}$ Thus, it is emphasized that when looking at the concept of programmatic vulnerability, it becomes possible to identify the different axes tied to adhesion to treatment that make up this concept.

Adhesion to antiretroviral treatment should be considered priority in assistance activities to health and HIV epidemic control in the country, and the role of health services is to articulate strategies that allow maintaining the adhesion. Thus, it was aimed to analyze, from the scientific production, the actions of the health service that contribute to improved adhesion to antiretroviral treatment for HIV, from axes that make up the programmatic vulnerability. 


\section{METHOD}

Study of narrative literature review type. To carry out this review the following steps were followed: preparation of the research question, data collection, data evaluation, analysis and interpretation of results, and finally the presentation of results. ${ }^{6}$

The research question of the study was: what are the health service actions that contribute to improved adhesion to antiretroviral treatment for HIV? There was searching in the Virtual Health Library (BVS), the Latin American and Caribbean Health Sciences databases (LILACS) and the International Literature on Health Sciences (MEDLINE), with the descriptors used ("medication adherence") and ((“HIV") or Acquired Immune Deficiency Syndrome).

The selection of productions in the databases occurred in February 2015. Inclusion criteria were: original articles available in full online and for free; published by 2014; in Portuguese, English or Spanish. As exclusion criteria there were: articles without abstract or with an incomplete abstract in the database. It is noteworthy that the articles that have been identified in more than one database were counted only once for access to the full text.

There were 38 productions found in LILACS and 186 in MEDLINE. The articles identification step occurred first, by reading the titles and abstracts. Those who met the inclusion and exclusion criteria, the entire article was readi, of which 16 productions were analyzed (Figure 1).

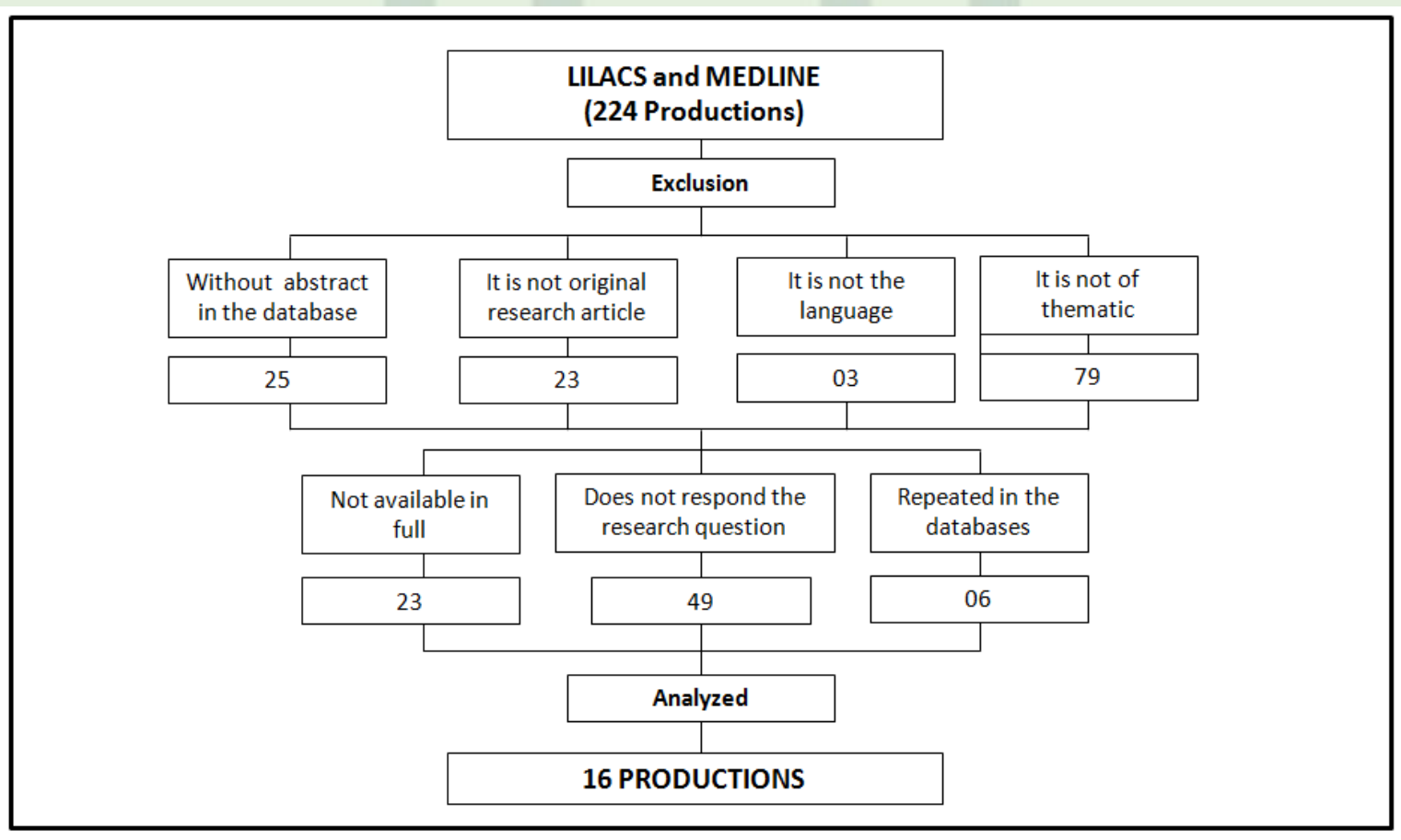

Figure 1 - Exclusion of productions flowchart. LILACS and MEDLINE, 2014.

For the collection and analysis of data an instrument was used, which included the following information: article identification, reference, results and limitations/recommendations of the studies. The articles were also characterized according to the publication year, area of expertise and origin. 
The analysis of production was through thematic content analysis, ${ }^{7}$ with theoretical categorization previously established through three axes composing the programmatic vulnerability reference (the commitment and responsibility of professionals and staff, access to health services; and organization of services). From this, health actions that were aimed at improving adhesion to treatment relative to each axis of programmatic vulnerability were sought in scientific production.

To show the results in order to organize and represent health actions that contributed for adhesion, a figure was prepared to outline the relationship between the axes of programmatic vulnerability and actions that contribute towards adherece (Figure 2) and a summary table was built (Frame 1), with the reference of the studies analyzed. Productions were article identified by the letter $A$, followed by a number ( $A 1, A 2, A 3 \ldots$ successively).

According to ethical aspects of this study, the precepts of Law 9,610/98 were followed in order to preserve and respect the ideas, concepts and definitions of the authors of the analyzed productions, being described and quoted according to the submission standards of this journal.

\section{RESULTS AND DISCUSSION}

According to the characterization of the studies, the year of publication with the highest prevalence was 2011, with four productions, where medicine was the knowledge area with the highest number of publications with six productions and Brazil was the country with most articles, with six productions (Table 1).

Table 1 - Characterization of the productions according to the year, knowledge area and origin. LILACS and MEDLINE, 2014.

\begin{tabular}{ll}
\hline \multicolumn{1}{c}{ Variables } & $N$ \\
\hline Year of Publication & 03 \\
2014 & 01 \\
2013 & 03 \\
2012 & 04 \\
2011 & 03 \\
2010 & 02 \\
2009 & \\
Knowkedge area & 05 \\
Nursing & 03 \\
Psychology & 06 \\
Medicine & 02 \\
Pharmacy & \\
Origin & 06 \\
Brazil & 02 \\
Colombia & 01 \\
India & 05 \\
USA & 02 \\
Ethiopy & \\
\hline
\end{tabular}


Scientific productions on adhesion aspects to antiretroviral treatment for HIV and its interrelation with the programmatic vulnerability pointed out as main results the commitment and responsibility of professionals and staff; access to health care; and organization (Figure 2).

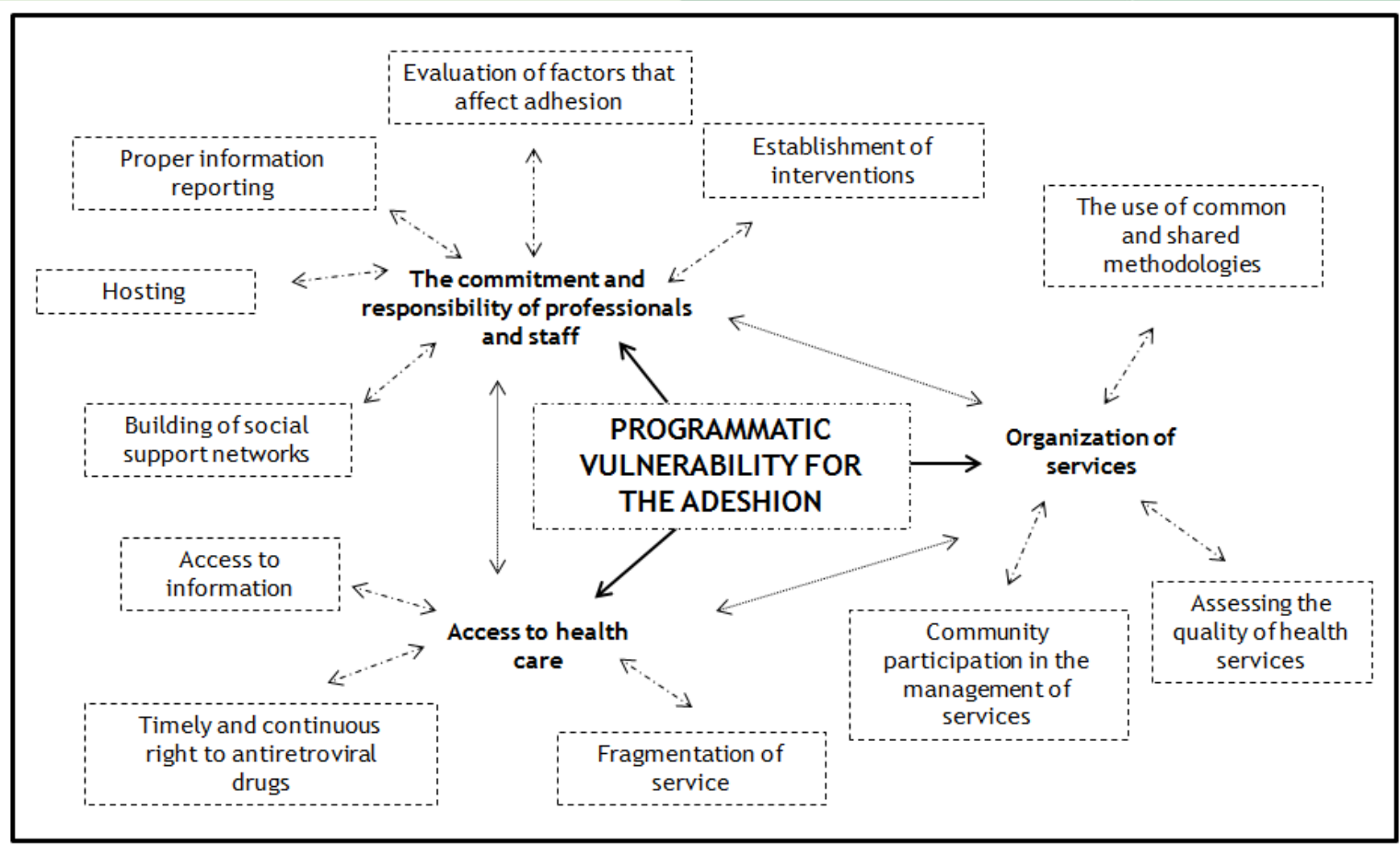

Figure 2 - Adhesion to antiretroviral treatment and its interrelation with the programmatic vulnerability. LILACS and MEDLINE, 2014.

The commitment and responsibility of professionals and staff in the adhesion are considered programmatic vulnerability aspects. With this axis, the productions showed the following health actions that would contribute to the improvement of adhesion: proper information reporting; evaluation of factors that affect adhesion; hosting; establishment of interventions; and building of social support networks.

This commitment and responsibility towards the adhesion may be established through a set of activities and should not only be a responsibility of the person performing the treatment, but also of health professionals, and signed a relationship between them, where each one knows their roles. ${ }^{8,9}$ For the adhesion success there are three levels of commitment highlighted, the first related the health service, which requires efficient, effective and resolute professionals, the second related to quality of care delivered by professionals, and then the subject's. ${ }^{10}$

The health service that keeps this commitment and responsibility build links, allowing communication between people on treatment, and consequently in better adhesion levels. Thus, the professional attitude together with the subject being treated, should prioritize the host to meet the specific needs, and allow people to participate in planning and decision about their own treatment. ${ }^{11}$

Proper communication of information by the staff (A1-A5) contributes to adhesion, requiring that a simple and objective language mediates the explanations concerning the treatment. This action taken by the health service, together with the people who are in 
treatment, allows the construction of tolerable forms for use of antiretroviral regimens and strategies to minimize the chances of forgetting to comply with drug prescriptions.

When understanding the proper reporting on adhesion composing the programmatic vulnerability plan, it is essential to valorize an affordable and consistent communication to the needs of each one in health practices. Traditionally, the individuals that values the professional competence in the use of their language and the clarity of their speech, either in an informative or prescriptive way, have a positive impact on adhesion to treatment. ${ }^{12}$

The evaluation of the factors that affect adhesion (A1, A5, A6), it is necessary to know the specifics and material and psychosocial difficulties of each person on antiretroviral therapy, to unveil aspects that can motivate them following the treatment. This review affects the adhesion and should be used as a strategy to support the subject in their treatment. It also assists the healthcare team to identify the difficulties to carry out the treatment, which allows to meet the demands and needs. It should be used as a help feature and not to blame them for the difficulties to adhere to antiretroviral treatment. ${ }^{3}$

The hosting (A6, A7) of the health team has the intention to maintain efforts for people to be one of the priorities in the health service in order to avoid abandoning treatment and to ensure adhesion to antiretroviral treatment. This hosting is constituted as a challenge in the possibility of building a comprehensive care and is one of the key elements to ensure quality of service. This can be considered an essential strategy for the establishment of a unique work process, implementing the relationships between the people who perform the treatment and health professionals. ${ }^{13}$

The establishment of interventions focused on adhesion, aims to contribute to the treatment monitoring $(A 2, A 3, A 5, A 6, A 8)$. The health service is a strategic location to promote interventions to establish information about the importance of adhesion. One of the interventions established by health services is the nursing consultation, developed through counseling and the establishment of a space for listening and dialogue for people with a view to develop joint strategies for the follow-up of antiretroviral treatment.

To carry out interventions to people on antiretroviral treatment, it is essential that health professionals be prepared to identify the key factors that minimize the adhesion to antiretroviral treatment, among which stands out the availability of access to services, frequency and laboratory tests, lack consultations, the delay in withdrawal of medicines, as well as of individual and social factors, thus, proposing interventions that enable the promotion of adhesion from the proposed treatment. ${ }^{14}$

For example, the nursing consultation may subsidize conditions to allow direct and independent action, emerging as a major healthcare instrument that enhances the subject to participate in their care process. In addition, it seeks to promote support in this intervention, the hosting, the interaction, listening and dialogue with the subject in an educational setting time suitable for sharing knowledge and closer ties between subject and staff. ${ }^{15}$

Another intervention is the development of a supervised home medication program. To identify people who are not keeping the adhesion, the health service is able to maintain continuity to the treatment, and the professional responsible for supervising and controlling the intake of medicines in the pre-set times on prescription. It emphasizes the implementation of an accompanying program with phone in order to remember the time to 
take the medication. This program was developed in two ways: phone call or message. Thus, these interventions by the health service has an impact on adhesion to antiretroviral treatment.

The elaboration of a supervised home medication program is not widely used in the context of HIV, having greater impact on tuberculosis control. However, it is emphasized that combined drug regimens that allow a single dose per day may be administered in a supervised manner, and it has shown good results in Brazil, as well as in countries with few resources or health infrastructure. ${ }^{16}$

Building social support networks to people being treated for HIV (A2, A3, A5, A6, A9, A10) becomes essential to establish the involvement shared between health professionals. This construction can occur through the development of support groups and makes it possible to stimulate the subject, since to maintain adhesion to treatment is necessary to overcome numerous difficulties within the health services. These difficulties are linked to a network of social support, which is sensitive, active and reliable, and which acts as support and referral agent enables the improved self-esteem, ultimately subsidizes health both physical and mental aspects as in psychological and affective-emotional. ${ }^{17}$

Access to health care in adhesion is considered an aspect of programmatic vulnerability which grouped: timely and continuous right to antiretroviral drugs; access to information; and fragmentation of service.

Access to health care in the programmatic vulnerability perspective can both may be related to drug treatment, as the clinical care and may be considered an important factor in adhesion to antiretroviral treatment. In Brazil, access to drug treatment guided in this free distribution policy of antiretroviral drugs for people living with HIV. However, there are still many issues that are linked to programmatic vulnerability that hinder treatment compliance. ${ }^{14}$

The timely and continuous right to antiretroviral drugs (A4, A5, A11) allow the continuity of care, and the delivery of antiretroviral drugs is a way to the service keeping the adhesion. Access to information on health services (A7, A9, A12, A13), enables the ongoing monitoring and assessment of antiretrovirals dispensations and enables quick identification of people with irregular withdrawal or at risk of noncompliance. Thus reduces the impact and consequences of non-adhesion for people living with HIV and for specialized public services.

The timely and continuous right to antiretroviral drugs is considered an action that ensures the distribution of medicines to enable adhesion to treatment. This right is mediated by Federal Law 9,313/96, which ensures universal access to antiretroviral treatment, being federal government's responsibility to ensure continuously antiretroviral drugs to all individuals who need them. ${ }^{18}$

The ease of access to information on antiretroviral treatment contributed to its adhesion. The health service can be considered a space that allows the establishment of intervention and treatment information. Thus, the availability of information on the relevance of adhesion, allows the health professional and the subject reassess the adequacy needs, in order to minimize interference that treatment can result in daily life. ${ }^{19}$

The fragmentation of the service $(\mathrm{A} 4, \mathrm{~A} 11)$ is considered problematic for treatment maintenance. Bureaucracy imposed by the fragmentation of the health service is perceived 
as a barrier to adhesion. Thus, the role of specialized pharmacies in HIV services which can be effective ways to help people achieve adhesion and persistence in performing the treatment is highlighted.

Health services that offer a fragmented structure can be a problem for people who carry HIV treatment, because it hinders their access and establishing strategies. The health services that still have a fragmentation in care for people living with HIV, yet perpetuate the establishment of a health practice model that interferes with the establishment of a comprehensive approach and can thus interfere with adhesion. ${ }^{20}$

The organization of services for adhesion is another aspect of programmatic vulnerability that grouped: the use of common and shared methodologies; community participation in the management of services; and assessing the quality of health services.

The health service organization is interrelated to the programmatic vulnerability, being considered a factor that may contribute to no treatment maintenance. Thus, the service of the organization includes a quality of care in caring for adhesion, ensuring the hosting, respecting psychosocial needs, leading the individual to recognize the service and the professionals that act as partners in their health recovery. ${ }^{21}$

The use of common and shared methodologies by the entire team (A7), contributes to the adhesion, although health services have mostly multidisciplinary teams. It is necessary that the type of care and the methodology used for all are common and shared, so people living with HIV have a comprehensive and continued care. The actions carried out together with all the staff contribute to the care and follow-up of antiretroviral treatment. Adhesion is considered as a dynamic and multifactorial process that requires shared decisions within the health service and the co-responsibility of subject, health team and its social context. ${ }^{22}$

Community participation in the management of services (A14) contributes to the development of public policies and the establishment of strategies that will meet the specific needs of the individuals who perform the treatment for HIV. Regarding to community participation in the management of services, establishing a shared process on accession strategies is important, linking the view of professionals and patients about treatment. This link between service and community, allows an improvement in adhesion, which consequently are involved in an active participation of people in their own treatment plan, with significant repercussions in the construction of their adhesion to treatment. ${ }^{8,23}$

The evaluation of the quality of health services (A13, A15, A16), allows healthcare perform ongoing assessments of the quality of their service in order to reverse the causes of non-adhesion to antiretroviral treatment. This review is considered a way of improving the service strategies for adhesion to antiretroviral treatment. This occurs through an assessment, which seeks to understand the complexity of the service and its professionals available, and requiring the continuous distribution of medicines, constant examinations, abandonment of control and absence, among others. ${ }^{24}$ 


\section{CONCLUSION}

The commitment and responsibility of health professionals is an important means of contributing to the adhesion of the person living with HIV to antiretroviral treatment. Health services that establish host and communication actions make people understand the information about their treatment. The construction of a link between subject-professional strengthens the construction of social support networks, allowing to identify the factors that influence adhesion and establish the construction of interventions that may contribute to improved adhesion.

Access to health services is another aspect that may interfere with adhesion, especially when this is mediated by a fragmented and bureaucratic service. When enabling the timely and continuing right treatment and the opportunity of providing information about their needs, the health service contribute to the achievement of treatment.

The organization of health services enables people on antiretroviral treatment to maintain adhesion. This organization, when combined with the evaluation of quality of care and treatment decisions that are shared with other team members, contributes to the maintenance of adhesion.

Health services in order to promote the health of people on antiretroviral treatment for HIV and minimize the issues surrounding the programmatic vulnerability and adhesion can establish its practices with commitment and responsibility, ensuring the service organization, as well as access to health actions that reflect the needs of each individual and integral care and co-responsibility of people for their treatment. 


\section{REFERENCES}

1 - Brasil, Ministério da Saúde. Secretaria de Vigilância em Saúde. Programa Nacional de DST e Aids. Protocolo clínico e diretrizes terapêuticas para manejo da infecção pelo HIV em adultos, 2013.

2 - Organização Mundial de Saúde (OMS). Cuidados inovadores para as condições crônicas: componentes estruturais de ação: relatório mundial. Brasília (DF): OMS; 2003.

3 - Polejack L, Seidl EMF. Monitoramento e avaliação da adesão ao tratamento antirretroviral para HIV/Aids: desafios e possibilidades. Ciênc saúde coletiva. 2010; 15(supl.10):1201-1208.

4 - Ayres JRCM, Calazans GJ, Saletti Filho HC, Junior IF. Risco, vulnerabilidade e práticas de prevenção e promoção da saúde. In: Campos GWS, Minayo MCS, Akerman M, Drumond Júnior M, Carvalho YM. Tratado de Saúde Coletiva. São Paulo: Huditec; Rio de Janeiro: Fiocruz; 2009. P. 375-417.

5 - Calazans GJ, Filho HCS, Júnio IF, Ayres JRCM. O conceito de vulnerabilidade. In: Padoin SMM, Paula CC, Schaurich D, Fontoura VA (Org). Experiências Interdisciplinares em aids: interfaces de uma epidemia. Editora UFSM: Santa Maria. 2006. P. 43-62.

6 - Rother ET. Revisão sistemática X revisão narrativa. Acta Paul Enferm. 2007; 20(2): 5-6.

7 - Minayo MCS. O desafio do conhecimento- pesquisa qualitativa em saúde. 12 ed. São Paulo: Hucitec:2010.

8 - Gir E, Vaichulonis CG, Oliveira MD. Adesão à terapêutica anti-retroviral por indivíduos com HIV/AIDS assistidos em uma instituição do interior paulista. Rev latinoam enferm. 2005;13(5):634641.

9 - Colombrini MRC, Coleta MFD, Lopes MHBM. Fatores de risco para a não adesão ao tratamento com terapia antirretroviral altamente eficaz. Rev Esc Enferm USP. 2008; 42(3):490-495.

10 - Guaragna BFP, Ludwig MLM, Cruz ALP, Graciotto A, Schatkoski AM. Implantação do programa de adesão ao tratamento de HIV/AIDS: Relato de experiência. Revista HCPA. 2007; 27(2):35-38.

11 - Seidl EMF, Mechíades A, Farias V, Brito A. Pessoas vivendo com HIV/AIDS: variáveis associadas à adesão ao tratamento antirretroviral. Cad Saúde Pública. 2007;23(1):2305-2316.

12 - Bellenzani R, Nemes MIB, Paiva V. Comunicação profissional-paciente e cuidado: avaliação de uma intervenção para adesão ao tratamento de HIV/AIDS. Interface comum saúde educ. 2013;17(47):803-834.

13 - Abrão FMS, Angelim RCM, Cardoso MD, Queiroz SBA, Freitas RMM, Oliveira DC. Características estruturais e organizacionais de serviços de assistência especializada em HIV/AIDS na cidade de Recife, Brasil. Rev baiana saúde pública. 2014;38(1):140-154.

14 - Colombrini MRC, Lopes MHBM, Figueiredo RM. Adesão à terapia antirretroviral para HIV/AIDS. Rev Esc Enferm USP. 2006;40(4):576-581.

15 - Macedo SM, Senna MCS, Miranda KCL. Consulta de enfermagem ao paciente com HIV: perspectivas e desafios sob a ótica de enfermeiros. Rev Bras Enferm. 2013; 66(2):196-201.

16 - Vitória MAA. Adesão ao tratamento anti-retroviral: o que podemos fazer para melhorar? In: Ministério da Saúde. Manual de assistência psiquiátrica em HIV/AIDS. Brasília: Ministério da Saúde. 2005. 
17 - Silva ALCN, Waidman MAP, Marcon SS. Adesão e não adesão à terapia antirretroviral: as duas faces de uma mesma evidência. Rev Bras de Enferm. 2009; 62(2):213-220.

18 - Hallal R, Ravasi G, Kuchenbecker R, Greco D, Simão M. O acesso universal ao tratamento antirretroviral no Brasil. Rev Tempus Actas em saúde coletiva. 2010; 4(2):53-66.

19 - Bonolo PF, Gomes RRF, Guimarães MDC. Adesão à terapia antirretroviral (HIV/AIDS): fatores associados e medidas da adesão. Epidemiol Serv Saúde. 2007 Nov. 16(4): 261-278.

20 - Borges MJL, Sampaio AS, Gurgel IGD. Trabalho em equipe e interdisciplinaridade: desafios para a efetivação da integralidade na assistência ambulatorial às pessoas vivendo com HIV/AIDS em Pernambuco. Ciênc saúde coletiva. 2012. 17(1): 147-156.

21 - Neves LAS, Reis RK, Gir E. Adesão ao tratamento por indivíduos com a co-infecção HIV/tuberculose: revisão integrativa da literatura. Rev Esc Enferm USP. 2010;44(4):1135-1141.

22 - Ilias M, Carandina LM, Marin MJS. Adesão à terapia antirretroviral de portadores do Vírus da Imunodeficiência Humana atendidos em um ambulatório da cidade de Marília, São Paulo. Rev Baiana de Saúde Pública. 2011; 35(2): 471-484.

23 - Fiuza MLT, Lopes EM, Alexandre HO, Dantas PB, Galvão MT, Pinheiro AKB. Adesão ao tratamento antirretroviral: assistência integral baseada no modelo de atenção às condições crônicas. Esc Anna Nery Rev Enferm. 2013; 17(4) 740-748.

24 - Nemes MIB, Castanheira ERL, Helena ETS, Melchior R, Caraciolo JM, Bsso CR, et al. Adesão ao tratamento, acesso e qualidade da assistência em AIDS no Brasil. Rev Assoc Med Bras. 2009; 55(2): 207-212.

\section{N. Referência}

A1 Felix G, Ceolim MF. The profile of women with HIV/AIDS and their adherence to the antiretroviral therapy. Rev Esc Enfem USP. 2012; 46(4):884-891.

A2 Almeida EL, Araújo GBS, Santos VA, Bustorff LACV, Pereira AVL, Dias MD. Adherence to treatment and factors that interfere with HIV positive and those living with AIDS. Rev Min Enferm. 2011; 15(2): 208-216.

A3 Kourrouski MFC, Lima RAG. Treatment adherence: the experience of adolescents with HIV/AIDS. Rev Latinoam Enferm. 2009; 17(6):16-22.

A4 Biressaw S, Abegaz WE, Abebe M, Taye WA, Belay M. Adherence to antiretroviral therapy and associated factors among HIV infected children in Ethiopia: unannounced home-based pill count versus caregiver' report. BMC Pediatrics. 2013; 13(132):1-9.

A5 Arrivillaga $M$, Ross $M$, Sringer A, Correa D. Applying an expanded social determinant approach to the concept of adherence to treatment: the case of Colombian women living with HIV/AIDS. Womwn's Health. 2011; 21(2):177-183.

A6 Santos WJ, Drumond EF, Gomes AS, Correa CM, Freitas MIF. Barriers and facilitators aspects of adherence to antiretroviral therapy in Belo Horizonte - MG. Rev Bras Enferm. 2011; 64(6):1028-1037.

A7 Gomes RRPM, Machado CJ, Acurcio FA, Guimarães MDC. Pharmacy records as na indicador of non-aderence to antiretroviral therapy by HIV-infected patients. Cad Saúde Pública. 2009; 25(3):495-506.

A8 Rodrigues R, Bogg L, Shet A, Kumar DS, Costa A. Mobile Phones To Sopport Adherence To Antiretroviral Therapy: What Would It Cost The Indian National AIDS Control Programme. Journal of the International AIDS Society. 2014; 17:19036. 
A9 Paschoal EP, Santo CCE, Gomes AMT, Santos EI, Oliveira DC, Pontes APM. Adesão à terapia antirretroviral e suas representações para pessoas vivendo com HIV/AIDS. Esc Anna Nery Rev Enferm. 2014; 18(1):32-40.

A10 Bezabhe WM, Chalmers L, Bereznicki LR, Peterson GM, Bimirew MA, Kassie DM. Barriers and facilitators of adherence to antiretroviral drug therapy and retention in care among adult HIV Positive patients: a qualitative study from Ethiopia. Plos One. 2014; 9(5):e97353.

A11 Arriviallaga-Quintero $M$. Analysis of barriers to therapeutic adherence for colombian women with HIV/AIDS: a questiono f health righits. Salud Publica Mex. 2010; 52:350-356.

A12 Murphy P, Cocohoba J, Tang A, Pietrandoni G, Hou J, Guglielmo J. Impact of HIVSpecialized Pharmacies on adherence and persistence with antiretroviral therapy. AIDS Patient Care and STDs. 2012; 26(9):526-531.

A13 Braithwaite RS, Fiellin DA, Nucifora K, Bryant K, Roberts M, Kim N, Justice A. Evaluations interventions to improve antiretroviral adherence: how much of an effect is required for favorable value? Value Health. 2010; 13(5):535-542.

A14 Bogart LM, Wagner GJ, Mutchler MG, Risley B, MCDavitt BW, Mckay T, et al. Community HIV Tratment advocacy programs may support treatment adherence. Aids Educ Prev. 2012; 24(1):1-14.

A15 Hirsch JD, Gonzales M, Rosenquist A, Miller TA, Gilmer TP, Best BM. Antiretroviral therapy adherence, medication use, and health care costs during 3 years of community pharmacy medication therapy management program for medi-cal beneficiaries with HIV/AIDS. J Manag Care Pharm. 2011;17(3):213-223.

A16 Kalichman SC, Gleber T. Stress and proverty predictors of treatment adherence among people with low-literacy living with HIV/AIDS. Psychosom Med. 2010; 72(8):810-816.

Quadro 1 - Adesão ao tratamento antirretroviral para o HIV e sua inter-relação com a vulnerabilidade programática - Síntese da revisão. LILACS e MEDLINE, 2014. 